\title{
PENGARUH KONSENTRASI AMPAS KECAP DAN KONSENTRASI WORTEL (Daucus carota) TERHADAP KARAKTERISTIK NUGGET NABATI
}

\author{
Yusep Ikrawan, Ina Siti Nurminabari, Fathurrahman Gunsan Putra \\ Program Studi Teknologi Pangan, Fakultas Teknik, Universitas Pasundan, Jl. Dr. Setiabudhi No.193, Bandung, 40153, \\ Indonesia \\ E-mail : yusepikrawan@unpas.ac.id
}

\begin{abstract}
Abstrak
Tujuan dari penelitian ini adalah untuk mengetahui pengaruh interaksi konsentrasi ampas kecap dan konsentrasi wortel terhadap karakteristik nugget nabati. Rancangan percobaan yang digunakan pada penelitian ini adalah pola faktorial (3x3) dalam Rancangan Acak Kelompok (RAK) dengan 3 kali ulangan. Rancangan perlakuan yang dilakukan pada penelitian ini terdiri dari dua faktor yaitu konsentrasi ampas kecap $(\mathrm{H})$ yang terdiri dari 3 taraf yaitu h1 (45\%), h2 (50\%), dan h3 (55\%) dan konsentrasi wortel (W) yang terdiri dari 3 taraf yaitu w1 (5\%), w2 (10\%), dan w3 (15\%). Respon organoleptik meliputi kenampakan, tekstur, aroma, dan rasa. Respon kimia meliputi kadar protein, kadar serat kasar, kadar air, dan kadar lemak. Hasil penelitian menunjukkan Konsentrasi ampas kecap $(\mathrm{H})$ berpengaruh terhadap kadar air, protein, serat kasar, lemak, kenampakan, aroma, rasa, dan tekstur. Konsentrasi wortel (W) berpengaruh terhadap serat kasar, kadar air, tekstur, rasa dan kenampakan tetapi tidak berpengaruh terhadap protein, lemak, dan aroma. Interaksi konsentrasi ampas kecap $(\mathrm{H})$ dan konsentrasi wortel $(\mathrm{W})$ berpengaruh terhadap kenampakan dan rasa tetapi tidak berpengaruh terhadap kadar air, protein, serat kasar, lemak, aroma, dan tekstur.
\end{abstract}

\begin{abstract}
The purpose of this research was to determine the interaction effect of soy sauce waste concentration and carrot concentration against characteristics of vegetable nuggets. Experimental design was used in this research is the pattern of factorial (3 x 3) in a Randomized Design Group (RDG) with three replicates. The design of treatment carried out on this research consisted of two factors, namely a concentration of soy sauce waste $(\mathrm{H})$ which consists of 3 levels namely $\mathrm{h} 1(45 \%), \mathrm{h} 2(50 \%)$, and the $\mathrm{h} 3(55 \%)$ and concentration of carrot $(\mathrm{W})$ which consists of 3 levels i.e. w1 (5\%), w2 $(10 \%)$, and w3 (15\%). Organoleptic response include appearance, textures, aroma and taste. Chemical response include protein, levels of coarse fibers, water rate and fat. The results showed the concentration of soy sauce waste $(\mathrm{H})$ affects the water content, protein, crude fiber, fat, appearance, aroma, taste, and texture. Carrot concentration (W) affects crude fiber, water content, texture, taste and appearance but does not affect protein, fat, and aroma. The interaction of soybean waste concentration $(\mathrm{H})$ and carrot concentration $(\mathrm{W})$ affects the appearance and taste but does not affect the water content, protein, crude fiber, fat, aroma, and texture.
\end{abstract}

Keywords: Keywords: Soy Sauce Waste, Carrot, Vegetable Nugget

\section{Pendahuluan}

Ampas kecap merupakan limbah atau sisa buangan hasil proses pembuatan kecap yang berbahan dasar kedelai hitam. Ampas kecap memiliki protein yang cukup tinggi berkisar $20-30 \%$. Untuk membuat kecap dibutuhkan bahan baku berupa biji kedelai. Ampas kecap dihasilkan sebesar 59,7\% dari bahan baku kedelai. Menurut Santoso (1987), ampas kecap per 100 gram memiliki energi $210 \mathrm{Kcal}$, protein $24,9 \%$, serat kasar 16,3\%, dan lemak 24,3\%.

Ampas kecap biasanya hanya dijadikan sebagai pakan ternak atau ditumis biasa oleh masyarakat sekitar. Pengolahan pangan pada ampas kecap masih sangat sedikit, padahal ampas kecap memiliki nilai gizi yang cukup tinggi terutama pada kadar protein nya. Salah satu contoh pengolahan pada ampas kecap dengan membuatnya menjadi nugget nabati.

Nugget adalah makanan setengah matang (ready to cook) yang umumnya terbuat dari daging yang dicincang, kemudian diberi bumbu (bawang putih, bawang bombai, garam, bumbu penyedap dan merica) yang dicetak dalam suatu wadah dan dikukus. Selanjutnya adonan didinginkan dan dipotong-potong dalam bentuk yang lebih kecil. Kemudian dicelupkan dengan putih telur dan dilapisi dengan tepung panir dan siap digoreng. Nugget merupakan salah satu bentuk makanan beku siap saji, yaitu produk yang mengalami pemanasan terlebih dahulu sehingga menghasilkan makanan setengah matang (precooked), kemudian dibekukan sehingga memiliki umur simpan yang cukup panjang.

Nugget dapat dibuat dari daging ayam, sapi, ikan dan lain-lain, namun yang popular dikalangan masyarakat adalah nugget ayam. Selain daging, nugget juga ada yang berbahan baku dari nabati sebagai pengganti daging. Masyarakat yang vegetarian pun dapat mengkonsumsi nugget nabati mengingat daging 
yang merupakan bahan baku diganti dengan bahan nabati.

Nugget nabati dapat dibuat dengan bahan baku berupa tempe, tahu, jamur, wortel, brokoli atau sayursayuran yang lain nya. Selain itu bahan baku nabati memiliki kandungan gizi seperti protein, vitamin, mineral, dan serat sehingga baik untuk tubuh.

Nugget merupakan salah satu jenis pangan yang beredar di masyarakat. Hal tersebut dikarenakan makanan ini merupakan produk pangan yang praktis dan tidak membutuhkan waktu yang lama untuk menyajikannya. Bahan dasar dalam pembuatan nugget menentukan karakteristik nugget yang dihasilkan. Biasanya digunakan berupa daging ayam, ikan, udang, maupun rajungan sebagai bahan utamanya. Akan tetapi, bahan dasar nugget yang berasal dari bahan makanan hewani harganya relatif mahal. Upaya agar harga nugget relatif lebih murah yaitu mencari alternatif bahan tambahan yang dapat dimanfaatkan sebagai bahan dasar tambahan nugget tetapi tetap mengandung protein tinggi (Saleh, 2002). Pada penelitian ini, untuk memperkaya gizi dari nugget ditambahkan wortel yang merupakan sumber gizi yang baik untuk kesehatan tubuh.

Pada nugget nabati biasanya ditambahkan jamur, sayur - sayuran, kacang, maupun tepung. Fungsi bahan tersebut adalah sebagai bahan pengisi dan meningkatkan nilai gizi pada nugget. Pada penelitian ini ditambahkan dengan bahan pengisi wortel mengingat wortel adalah sayuran dengan nilai gizi tinggi yang baik untuk kesehatan tubuh.

Wortel (Daucus carota) adalah jenis sayuran akar yang sering disebut sebagai makanan sehat karena mengandung berbagai nutrisi atau gizi yang tinggi. Wortel mengandung Beta Karoten, Serat, Vitamin A, Vitamin B6, Vitamin $\mathrm{K}$ dan Kalium yang tinggi sehingga memberikan banyak manfaat kesehatan bagi orang yang menkonsumsinya. Wortel merupakan sayuran berwarna oranye yang banyak digemari, karena rasanya yang enak dan manfaat wortel yang melimpah. Wortel bisa dimakan mentah, direbus, atau digoreng, dibuat jus, atau campuran puding.

Manfaat wortel didapat dari kandungan betakaroten di dalamnya, yang berguna sebagai antioksidan. Manfaat wortel juga didapat dari kandungan serat, vitamin $\mathrm{K}$, dan kalium. Wortel mengandung serat makanan yang bisamemperbaiki kondisi saluran pencernaan yang terganggu seperti diare atau konstipasi (Bjarnadottir, 2015).

\section{Bahan dan Metode Penelitian}

Bahan yang digunakan dalam pembuatan nugget ampas kecap adalah ampas kecap dari pabrik kecap di Majalengka, bahan tambahan berupa wortel sumatera dengan varietas nantes, bahan penunjang berupa tepung MOCAF, sari kedelai, gula, merica, bawang putih, bawang bombay, minyak goreng, telur, tepung roti vegevit. Bahan yang digunakan untuk analisis adalah HCL $0,1 \mathrm{~N}, \mathrm{NaOH} 0,1 \mathrm{~N}, \mathrm{H} 2 \mathrm{SO} 4$ pekat, aquadest, Na2S2O3 5\%, heksana, granula Zn, AgNO3, $\mathrm{K} 2 \mathrm{CrO} 4$, dan Silica gel.

Metode penelitian dilakukan dalam dua tahap yaitu penelitian pendahuluan dan penelitian utama. Penelitian pendahuluan yang akan dilakukan terhadap ampas kecap adalah analisis kadar $\mathrm{NaCl}$, kadar protein dan kadar serat. Sedangkan, penelitian utamayang akan dilakukan merupakan lanjutan dari penelitian pendahuluan meliputi rancangan perlakuan, rancangan percobaan, rancangan analisis dan rancangan respon.

Rancangan perlakuan terdiri dari dua faktor yaitu konsentrasi bahan baku ampas kecap $(\mathrm{H})$ dan konsentrasi wortel (W) terhadap pembuatan nugget nabati yang terdiri dari 3 taraf. Faktor konsentrasi ampas kecap $(\mathrm{H})$ terdiri dari 3 taraf, yaitu $\mathrm{h} 1=45 \%, \mathrm{~h} 2=50 \%$, $\mathrm{h} 3=55 \%$. Faktor konsentrasi wortel $(\mathrm{W})$ terdiri dari 3 taraf, yaitu $\mathrm{w} 1=5 \%, \mathrm{w} 2=10 \%, \mathrm{w} 3=15 \%$

Model rancangan percobaan yang digunakan dalam pembuatan nugget nabati adalah rancangan faktorial 3x3 dalam rancangan acak kelompok (RAK) dengan 3 kali pengulangan, sehingga diperoleh 27 satuan perlakuan

Rancangan respon meliputi analisis kimia dan uji organoleptik. Analisis kimia yang dilakukan meliputi: analisis kadar protein dengan metode Kjedahl (Sudarmadji, 2010), analisis kadar serat kasar dengan metode Gravimetri, analisis kadar lemak dengan metode Soxhlet, dan analisis kadar air dengan metode Gravimetri Uji organoleptik yang digunakan adalah metode uji hedonik yang dilakukan untuk mengetahui kesan panelis berdasarkan kesukaan panelis. Uji organoleptik ini dapat menentukan suatu produk diterima atau tidak oleh konsumen yang diwakili oleh panelis sebagai penilaian sebanyak 30 panelis. Penilaian dilakukan terhadap atribut tekstur, rasa, dan aroma dengan skala hedonik.

\section{Persiapan Bahan Baku Ampas Kecap}

Persiapan ampas kecap mula-mula dilakukan sortasi untuk dibuang kotoran dan batu pada ampas kecap, kemudian dilakukan perendaman selama 24 jam pada air bersih. Ampas kecap kemudian disaring dan diblanching dengan uap air pada suhu $100^{\circ} \mathrm{C}$ selama 5 menit.

\section{Persiapan Bahan Tambahan Wortel}

Persiapan wortel diawali dengan sortasi untuk dipisahkan dari bagian wortel yang tidak diperlukan, kemudian dilakukan proses pencucian. Wortel yang sudah dicuci kemudian direduksi ukuran dengan menggunakan pemarut wortel.

\section{Pembuatan Nugget Nabati}

Ampas kecap yang telah dilakukan proses blanching selanjutnya dilakukan proses penggilingan berfungsi untuk memperkecil ukuran ampas kecap sehingga memudahkan pencampuran bahan yang homogen. Ampas kecap kemudian dicampurkan dengan bahan - bahan lain yaitu wortel, tepung MOCAF, sari 
kedelai, gula, merica, penyedap rasa, bawang bombay, dan bawang putih yang dilakukan penumisan terlebih dahulu. Semua bahan dicampur dan diaduk hingga membentuk adonan kemudian dicetak pada loyang yang sudah diolesi mentega atau minyak goreng dengan ukuran $20 \times 20 \mathrm{~cm}$. Adonan yang dicetak kemudian dikukus selama 45 menit, kemudian dilakukan penurunan suhu disuhu kamar. Hasil pengukusan tersebut kemudian dipotong menjadi ukuran $5 \times 3 \times 1 \mathrm{~cm}$. Setelah dipotong, dilakukan pelapisan I yaitu nugget dilapisi dengan tepung MOCAF, kemudian dilakukan pelapisan II yaitu nugget dilapisi dengan putih telur, dan terakhir dilakukan pelapisan III yaitu nugget dilapisi dengan tepung roti. Hasil pelapisan kemudian disimpan dalam freezer selama 30 menit. Nugget pun siap digoreng dengan minyak mendidih

\section{Hasil dan Pembahasan}

\section{Penelitian Pendahuluan}

Penelitian pendahuluan dilakukan untuk mengetahui kadar protein dan kadar serat kasar pada ampas kecap serta mengetahui pengaruh proses perendaman ampas kecap terhadap kadar $\mathrm{NaCl}$ dengan lama perendaman selama 24 jam.

Berdasarkan hasil pengujian, ampas kecap memiliki kadar protein sebesar $16,98 \%$ dan kadar serat kasar 13,3\%. Perendaman ampas kecap selama 24 jam mempengaruhi kadar $\mathrm{NaCl}$. Perendaman selama 24 jam menurunkan kadar $\mathrm{NaCl} 11,68 \%$ menjadi 4,76\%.

\section{Penelitian Utama}

Penelitian utama merupakan penelitian lanjutan dari penelitian pendahuluan. Pada penelitian utama dilakukan pengamatan nugget nabati menggunakan ampas kecap yang sudah direndam sebelumnya pada penelitian pendahuluan sebagai bahan baku utama dan penambahan konsentrasi wortel. Penelitian utama yang dilakukan bertujuan untuk mengetahui pengaruh konsentrasi ampas kecap dan konsentrasi wortel terhadap nugget nabati.

Nugget nabati yang dihasilkan dilakukan analisis kimia meliputi analisis kadar protein dengan metode Kjedahl, analisis kadar serat kasar dengan metode Gravimetri, analisis kadar air dengan metode Gravimetri, dan analisis kadar lemak dengan metode Soxhlet. Hasil selanjutnya dilakukan pengujian secara organoleptik untuk mengetahui tingkat kesukaan penerimaan panelis terhadap produk dengan metode uji hedonik dengan atribut kenampakan, rasa, tekstur, dan aroma.

\section{Respon kimia}

\section{a. Kadar Protein}

Protein merupakan suatu zat makanan yang amat penting bagi tubuh karena zat ini disamping berfungsi sebagai bahan bakar dalam tubuh juga berfungsi sebagai zat pembangun dan pengatur. Protein adalah sumber asam-asam amino yang mengandung unsur $\mathrm{C}, \mathrm{H}, \mathrm{O}$ dan $\mathrm{N}$ yang tidak dimiliki oleh lemak dan karbohidrat.
Fungsi utama protein bagi tubuh ialah untuk membentuk jaringan baru dan mempertahankan jaringan yang telah ada (Winarno, 2008).

Berdasarkan hasil analisis variansi, menunjukkan bahwa faktor $\mathrm{H}$ (konsentrasi ampas kecap) berpengaruh nyata terhadap kandungan protein nugget nabati, sedangkan faktor W (konsentrasi wortel) dan interaksi HW (konsentrasi ampas kecap dan konsentrasi wortel) tidak berpengaruh nyata terhadap kandungan protein nugget nabati. Pengaruh interaksi konsentrasi ampas kecap dan konsentrasi wortel dapat dilihat pada tabel 1 .

Tabel 1. Pengaruh Konsentrasi Ampas Kecap terhadap Kadar Protein Nugget Nabati

\begin{tabular}{|c|c|}
\hline $\begin{array}{c}\text { Konsentrasi Ampas Kecap } \\
(\mathrm{H})\end{array}$ & Kadar Protein (\%) \\
\hline h1 (45\%) & $14,58 \mathrm{a}$ \\
\hline h2 (50\%) & $16,08 \mathrm{~b}$ \\
\hline h3 (55\%) & $17,28 \mathrm{c}$ \\
\hline
\end{tabular}

Keterangan : Setiap huruf yang berbeda menunjukkan perbedaan yang nyata berdasarkan Uji Lanjut Duncan pada taraf 5\%

Hasil analisis kadar protein dapat diketahui bahwa perlakuan h1 (konsentrasi ampas kecap 45\%) berbeda nyata dengan perlakuan h2 (konsentrasi ampas kecap $50 \%$ ) dan h3 (konsentrasi ampas kecap 55\%). Semakin tinggi penambahan ampas kecap pada nugget nabati maka kadar protein semakin tinggi. Kadar protein setiap perlakuan berbeda-beda, hal ini sesuai dengan kadar protein yang terkandung pada setiap bahan yang dicampurkan. Kadar protein pada nugget semakin bertambah dengan semakin bertambahnya ampas kecap karena ampas kecap memiliki kadar protein yang tinggi dan sumber protein terbesar pada nugget. Protein ampas kecap pada penelitian pendahuluan didapat hasil $16,98 \%$

\section{b.Kadar Serat Kasar}

Serat kasar adalah salah satu jenis polisakarida atau sering disebut karbohidrat kompleks. Serat kasar ini mempunyai rantai kimiawi panjang sehingga sukar untuk dicerna oleh enzim dan saluran pencernaan manusia, meskipun ada beberapa yang dapat dicerna oleh bakteri dalam usus. Komposisi kimia serat pangan bervariasi tergantung dari komposisi dinding sel tanaman penghasilnya. Komponen - komponen penyusun dinding sel terdiri atas selulosa, hemiselulosa, pektin, lignin, gum, dan mukilase yang kesemuanya ini termasuk ke dalam serat pangan (Tensiska, 2018).

Berdasarkan hasil analisis variansi, bahwa faktor $\mathrm{H}$ (konsentrasi ampas kecap) dan faktor W (konsentrasi wortel) berpengaruh nyata terhadap kadar serat kasar nugget nabati, namun interaksi HW (konsentrasi ampas kecap dan konsentrasi wortek) tidak berpengaruh nyata terhadap kadar serat kasar nugget nabati. Pengaruh konsentrasi ampas kecap dan konsentrasi wortel terhadap kadar serat kasar dapat dilihat pada tabel 2 dan 3. 
Tabel 2. Pengaruh Konsentrasi Ampas Kecap terhadap Kadar Serat Kasar Nugget Nabati

\begin{tabular}{|c|c|}
\hline $\begin{array}{c}\text { Konsentrasi Ampas Kecap } \\
(\mathrm{H})\end{array}$ & Serat Kasar (\%) \\
\hline $\mathrm{h} 1(45 \%)$ & $7,67 \mathrm{a}$ \\
\hline $\mathrm{h} 2(50 \%)$ & $9,89 \mathrm{~b}$ \\
\hline $\mathrm{h} 3(55 \%)$ & $10,89 \mathrm{~b}$ \\
\hline $\begin{array}{l}\text { Keterangan: Setiap huruf yang berbeda menunjukkan } \\
\text { perbedaan yang nyata berdasarkan Uji Lanjut Duncan pada taraf 5\% }\end{array}$
\end{tabular}

Hasil analisis variansi kadar serat kasar pada tabel 2 menunjukkan hasil pada perlakuan h2 (konsentrasi ampas kecap 50\%) dan h3 (konsentrasi ampas kecap $55 \%$ ) berbeda nyata dengan perlakuan h1 (konsentrasi ampas kecap 45\%). Hal ini disebabkan karena penambahan ampas kecap yang semakin besar, semakin besar juga kadar serat pada nugget nabati. Kandungan serat ampas kecap pada penelitian pendahuluan didapat hasil sebesar $13,3 \%$. Kadar serat ampas kecap yang cukup tinggi sangat mempengaruhi kadar serat kasar pada nugget dengan setiap penambahan ampas kecap.

United State Food Dietary Analysis menganjurkan total dietary fiber adalah $25 \mathrm{~g} / 2000$ kalori atau $30 \mathrm{~g} / 2500$ kalori. Sedangkan American Diabetic Assosiation menetapkan kebutuhan serat 25-50g/hari untuk pencegahan penyakit diabetes. Pada sensus nasional pengelolaan diabetes di Indonesia disarankan konsumsi serat sebanyak 25g/hari (Anonim, 2016).

Tabel 3. Pengaruh Konsentrasi Wortel terhadap Kadar Serat Kasar Nugget Nabati

\begin{tabular}{|c|c|}
\hline Konsentrasi Wortel (W) & Serat Kasar (\%) \\
\hline w1 (5\%) & $8,33 \mathrm{a}$ \\
\hline w2 (10\%) & $9,67 \mathrm{~b}$ \\
\hline w3 (15\%) & $10,44 \mathrm{~b}$ \\
\hline
\end{tabular}

Keterangan : Setiap huruf yang berbeda menunjukkan perbedaan yang nyata berdasarkan Uji Lanjut Duncan pada taraf $5 \%$.

Hasil analisis variansi kadar serat kasar pada tabel 3 menunjukkan hasil pada perlakuan w2 (konsentrasi wortel 10\%) dan w3 (konsentrasi wortel 15\%) berbeda nyata dengan perlakuan w1 (konsentrasi wortel 5\%). Hal ini disebabkan karena penambahan wortel yang semakin besar, semakin besar juga kadar serat pada nugget nabati., sedangkan kandungan serat wortel 2,8 gram per 100gram (USDA National Nutrient, 2007).

\section{c. Kadar Lemak}

Lemak merupakan zat makanan yang penting untuk menjaga kesehatan tubuh manusia. Lemak memiliki beberapa fungsi dalam tubuh, yaitu sebagai sumber energi dan pembentukan jaringan adipose. Lemak merupakan sumber energi paling tinggi yang menghasilkan 9 kkal untuk tiap gramnya, yaitu 2,5 kali energi yang dihasilkan oleh karbohidrat dan protein dalam jumlah yang sama (Almatsier, 2000). Menurut Koswara (2006), lemak akan menghasilkan asam-asam lemak dan kolestrol yang dibutuhkan untuk membentuk membrane sel pada semua organ. Akan tetapi, konsumsi lemak yang berlebihan akan menimbulkan kegemukan, meningkatkan resiko terkena penyakit jantung koroner dan penyakit degeneratif lainnya.

Berdasarkan hasil analisis variansi, menunjukkan bahwa faktor $\mathrm{H}$ (konsentrasi ampas kecap) berpengaruh nyata terhadap kandungan lemak nugget nabati, sedangkan faktor W (konsentrasi wortel) dan interaksi HW (konsentrasi ampas kecap dan konsentrasi wortel) tidak berpengaruh nyata terhadap kandungan lemak nugget nabati. Tabel pengaruh konsentrasi ampas kecap dapat dilihat pada tabel 4 .

Tabel 4. Pengaruh Konsentrasi Ampas Kecap terhadap Kadar Lemak Nugget Nabati

\begin{tabular}{|c|c|}
\hline $\begin{array}{c}\text { Konsentrasi Ampas Kecap } \\
(\mathrm{H})\end{array}$ & Lemak (\%) \\
\hline $\mathrm{h} 1(45 \%)$ & $2,53 \mathrm{a}$ \\
\hline $\mathrm{h} 2(50 \%)$ & $3,13 \mathrm{~b}$ \\
\hline $\mathrm{h} 3(55 \%)$ & $4,09 \mathrm{c}$ \\
\hline
\end{tabular}

Keterangan : Setiap huruf yang berbeda menunjukkan perbedaan yang nyata berdasarkan Uji Lanjut Duncan pada taraf 5\%

Hasil analisis kadar lemak dapat diketahui bahwa perlakuan h1 (konsentrasi ampas kecap 45\%) berbeda nyata dengan perlakuan h2 (konsentrasi ampas kecap $50 \%$ ) dan h3 (konsentrasi ampas kecap 55\%). Semakin tinggi penambahan ampas kecap pada nugget nabati maka kadar lemak semakin tinggi. Kadar lemak setiap perlakuan berbeda-beda, hal ini sesuai dengan kadar protein yang terkandung pada setiap bahan yang dicampurkan. Ampas kecap memiliki kadar lemak 1324 gram per 100 gram bahan (Widodo, 2001). Pada umumnya setelah proses pengolahan bahan pangan akan terjadi kerusakan lemak yang terkandung di dalamnya. Tingkat kerusakan lemak sangat bervariasi tergantung pada suhu yang digunakan dan lamanya waktu proses pengolahan. Makin tinggi suhu yang digunakan, maka semakin intens kerusakan lemak. Terjadinya penurunan kadar lemak setelah pengukusan disebabkan karena sifat lemak yang tidak tahan panas, selama proses pemasakan lemak mencair bahkan menguap (volatile) menjadi komponen lain seperti flavor (Dian Sundari, et.al, 2015).

\section{d. Kadar Air}

Air dalam bahan pangan berperan sebagai pelarut dari beberapa komponen di samping ikut sebagai bahan pereaksi, sedangkan bentuk air dapat ditemukan sebagai air bebas dan air terikat. Air bebas dapat dengan mudah hilang apabila terjadi penguapan atau pengeringan, sedangkan air terikat sulit dibebaskan dengan cara tersebut. Sebenarnya air dapat terikat secara fisik, yaitu ikatan menurut sistem kapiler dan air terikat secara kimia, antara lain air kristal dan air yang terikat dalam sistem dispersi (Purnomo,1995).

Berdasarkan hasil analisis variansi, menunjukkan bahwa faktor $\mathrm{H}$ (konsentrasi ampas kecap) dan faktor W (konsentrasi wortel) berpengaruh nyata terhadap kandungan air nugget nabati, sedangkan interaksi HW (konsentrasi ampas kecap dan konsentrasi wortel) tidak berpengaruh nyata terhadap kandungan air nugget 
nabati. Tabel pengaruh konsentrasi ampas kecap dan konsentrasi wortel dapat dilihat pada tabel 5 dan 6 .

Tabel 5. Pengaruh Konsentrasi Ampas Kecap terhadap Kadar Air Nugget Nabati

\begin{tabular}{|c|c|}
\hline $\begin{array}{c}\text { Konsentrasi Ampas Kecap } \\
(\mathrm{H})\end{array}$ & Kadar Air (\%) \\
\hline h1 $(45 \%)$ & $35,72 \mathrm{c}$ \\
\hline $\mathrm{h} 2(50 \%)$ & $34,60 \mathrm{~b}$ \\
\hline $\mathrm{h} 3(55 \%)$ & $33,61 \mathrm{a}$ \\
\hline
\end{tabular}

Keterangan : Setiap huruf yang berbeda menunjukkan perbedaan yang nyata berdasarkan Uji Lanjut Duncan pada taraf 5\%

Hasil analisis kadar air pada tabel 5 dapat diketahui bahwa perlakuan h1 (konsentrasi ampas kecap $45 \%$ ) berbeda nyata dengan perlakuan h2 (konsentrasi ampas kecap 50\%) dan h3 (konsentrasi ampas kecap $55 \%$ ). Semakin tinggi penambahan ampas kecap pada nugget nabati maka kadar air semakin rendah, hal ini disebabkan karena semakin banyak penambahan ampas kecap semakin berkurang penambahan sari kedelai yang merupakan sumber air yang besar.

Tabel 6. Pengaruh Konsentrasi Wortel terhadap Kadar Air Nugget Nabati

\begin{tabular}{|c|c|}
\hline Konsentrasi Wortel (W) & Kadar Air \\
\hline w1 (5\%) & $35,39 \mathrm{~b}$ \\
\hline w2 (10\%) & $34,39 \mathrm{a}$ \\
\hline w3 (15\%) & $34,14 \mathrm{a}$ \\
\hline
\end{tabular}

Keterangan : Setiap huruf yang berbeda menunjukkan perbedaan yang nyata berdasarkan Uji Lanjut Duncan pada taraf 5\%

Hasil analisis variansi kadar air pada tabel 6 menunjukkan hasil pada perlakuan w1 (konsentrasi wortel 10\%) berbeda nyata dengan perlakuan w1 (konsentrasi wortel 5\%) dan w3 (konsentrasi wortel $15 \%$ ). Hal ini disebabkan karena penambahan wortel yang semakin besar, semakin rendah kadar air pada nugget nabati, hal ini disebabkan karena semakin banyak penambahan wortel semakin berkurang penambahan sari kedelai yang merupakan sumber air yang besar.

\section{Respon Organoleptik}

Pengujian organoleptik dengan metode uji hedonik ini dilakukan untuk mengetahui tingkat kesan kesukaan yang menyangkut produk sehingga dapat mengetahui produk tersebut dapat diterima oleh masyarakat atau sebaliknya. Pengujian organoleptik ini dilakukan dengan melibatkan 30 orang panelis untuk mengetahui kesan yang ditimbulkan panelis yang mewakili masyarakat atau konsumen terhadap atribut kenampakan, rasa, tekstur, dan aroma nugget nabati.

\section{a. Kenampakan}

Hasil analisis variansi, bahwa faktor $\mathrm{H}$ (konsentrasi ampas kecap), faktor W (konsentrasi wortel) dan interaksi HW (konsentrasi ampas kecap dan konsentrasi wortel) berpengaruh nyata terhadap kenampakan nugget nabati. Tabel pengaruh interaksi konsentrasi ampas kecap dan konsentrasi wortel dapat dilihat pada tabel 7.

Tabel 7. Pengaruh Interaksi Konsentrasi Ampas Kecap dan Konsentrasi Wortel terhadap Kenampakan Nugget Nabati

\begin{tabular}{|c|c|c|c|}
\hline \multirow{2}{*}{$\begin{array}{c}\text { Konsentrasi ampas } \\
\text { kecap }(\mathrm{H})\end{array}$} & \multicolumn{3}{|c|}{ Konsentrasi wortel (W) } \\
\hline & $\begin{array}{c}\mathrm{w1} \\
(5 \%)\end{array}$ & w2 (10\%) & w3 (15\%) \\
\hline h1 (45\%) & $\begin{array}{cc}3,84 & \text { A } \\
\text { b } & \end{array}$ & 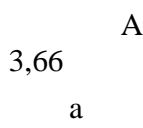 & 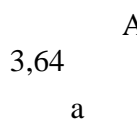 \\
\hline h2 (50\%) & $\begin{array}{rr}3,79 & \mathrm{~A} \\
\mathrm{a} & \end{array}$ & 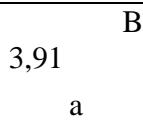 & 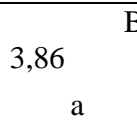 \\
\hline h3 $(55 \%)$ & $\begin{array}{rl}3,86 & \mathrm{~A} \\
\mathrm{~b} & \end{array}$ & $\begin{array}{ll} & \text { B } \\
3,80 & \\
\text { b } & \end{array}$ & $\begin{array}{rr} & \\
3,56 & \\
& \\
& \end{array}$ \\
\hline
\end{tabular}

Keterangan : Setiap huruf yang berbeda menunjukkan perbedaan yang nyata berdasarkan Uji Lanjut Duncan pada taraf 5\%. Huruf kecil dibaca horizontal, huruf kapital dibaca vertical

Hasil tabel 7 menunjukkan hasil organoleptik terhadap kenampakan nugget nabati pada perlakuan h1 (konsentrasi ampas kecap 45\%) berpengaruh nyata terhadap w1 (konsentrasi wortel 5\%) tapi tidak berpengaruh nyata terhadap w2 (konsentrasi wortel $10 \%$ ) dan w3 (konsentrasi wortel 15\%). Pada perlakuan h2 (konsentrasi ampas kecap 50\%) tidak berpengaruh nyata terhadap w1 (konsentrasi wortel 5\%), w2 (konsentrasi wortel 10\%), dan w3 (konsentrasi wortel 15\%). Pada perlakuan h3 (konsentrasi ampas kecap $55 \%$ ) berpengaruh nyata terhadap w1 (konsentrasi wortel 5\%) dan w2 (konsentrasi wortel 10\%), sedangkan w3 (konsentrasi wortel 15\%) tidak berpengaruh nyata. Pada perlakuan w1 (konsentrasi wortel 5\%) berpengaruh nyata terhadap h1 (konsentrasi ampas kecap 45\%) dan h3 (konsentrasi ampas kecap $55 \%$ ), tapi tidak berpengaruh nyata terhadap $\mathrm{h} 2$ (konsentrasi ampas kecap 50\%). Pada perlakuan w2 (konsentrasi wortel 10\%) berpengaruh nyata terhadap h3 (konsentrasi ampas kecap 55\%), tapi tidak berpengaruh nyata terhadap h1 (konsentrasi ampas kecap 45\%) dan h2 (konsentrasi ampas kecap 50\%). Pada perlakuan w3 tidak ada pengaruh nyata terhadap pelakuan h1 (konsentrasi ampas kecap 45\%), h2 (konsentrasi ampas kecap 50\%), dan h3 (konsentrasi ampas kecap 55\%).

Pada h2w2 memiliki nilai kesukaan tertinggi yaitu 3,91 yang menunjukkan bahwa penambahan ampas kecap dan wortel yang terlalu sedikit atau terlalu banyak, kenampakan nugget kurang disukai oleh panelis. Hal ini dikarenakan pada ampas kecap semakin banyak penambahan maka warna nugget semakin hitam sehingga kurang disukai oleh panelis, sedangkan jika terlalu sedikit penambahan ampas kecap warna akan semakin putih pucat karena hasil dari pencampuran ampas kecap dengan tepung MOCAF dan kurang 
disukai oleh panelis. Pada wortel semakin banyak penambahan maka warna semakin oranye, sedangkan jika sedikit penambahan maka warna semakin mendekati warna ampas kecap. Hasil tabel 7 menunjukkan interaksi terbaik terjadi pada interaksi $\mathrm{h} 2 \mathrm{w} 2$.

\section{b. Tekstur}

Berdasarkan hasil analisis variansi, menunjukkan bahwa faktor $\mathrm{H}$ (konsentrasi ampas kecap) dan faktor W (konsentrasi wortel) berpengaruh nyata terhadap tekstur nugget nabati, sedangkan interaksi HW (konsentrasi ampas kecap dan konsentrasi wortel) tidak berpengaruh nyata terhadap tekestur nugget nabati. Tabel pengaruh konsentrasi ampas kecap dan konsentrasi wortel dapat dilihat pada tabel 8 dan 9 .

Tabel 8. Pengaruh Konsentrasi Ampas Kecap terhadap Tekstur Nugget Nabati

\begin{tabular}{|c|c|}
\hline $\begin{array}{c}\text { Konsentrasi Ampas Kecap } \\
(\mathrm{H})\end{array}$ & Tekstur \\
\hline h1 (45\%) & $4,31 \mathrm{~b}$ \\
\hline h2 $(50 \%)$ & $4,31 \mathrm{~b}$ \\
\hline h3 $(55 \%)$ & $4,15 \mathrm{a}$ \\
\hline
\end{tabular}

Keterangan : Setiap huruf yang berbeda menunjukkan perbedaan yang nyata berdasarkan Uji Lanjut Duncan pada taraf 5\%

Hasil analisis tekstur pada tabel 8 dapat diketahui bahwa perlakuan h1 (konsentrasi ampas kecap 45\%) dan h2 (konsentrasi ampas kecap 50\%) berbeda nyata dengan perlakuan dan h3 (konsentrasi ampas kecap 55\%). Tabel 18 menunjukkan bahwa semakin bertambah ampas kecap, semakin kurang disukai oleh panelis.

Hal ini disebabkan karena ampas kecap mempunyai tekstur yang lembek. Tekstur lembek pada ampas kecap dipengaruhi oleh proses fermentasi. Kacang kedelai hitam difermentasi menggunakan ragi (Aspergillus sp. dan Rhizopus sp) menjadi tempe dan tekstur menjadi lembek. Fermentasi garam juga berpengaruh pada tekstur ampas kecap dimana kacang kedelai direndam pada larutan garam sehingga menambahkan air pada larutan akan masuk kedalam kacang kedelai membuat tekstur lebih lembek (Faiazal Sidiq, 2014). Perendaman pada ampas kecap sebelum diolah menjadi nugget juga mempengaruhi tekstur ampas kecap karena direndam pada air selama 24 jam sehingga kadar air pun semakin meningkat pada ampas kecap.

Tabel 9. Pengaruh Konsentrasi Wortel terhadap Tekstur Nugget Nabati

\begin{tabular}{|c|c|}
\hline Konsentrasi Wortel (W) & Tekstur \\
\hline w1 (5\%) & $4,29 \mathrm{~b}$ \\
\hline w2 (10\%) & $4,32 \mathrm{~b}$ \\
\hline w3 (15\%) & $4,16 \mathrm{a}$ \\
\hline
\end{tabular}

Keterangan : Setiap huruf yang berbeda menunjukkan perbedaan yang nyata berdasarkan Uji Lanjut Duncan pada taraf 5\%

\begin{tabular}{|c|c|c|c|}
\hline \multirow{2}{*}{$\begin{array}{l}\text { Konsentrasi } \\
\text { ampas kecap } \\
(\mathrm{H})\end{array}$} & \multicolumn{3}{|c|}{ Konsentrasi wortel (W) } \\
\hline & $\begin{array}{c}\text { w1 } \\
(5 \%)\end{array}$ & $\begin{array}{c}\text { w2 } \\
(10 \%)\end{array}$ & w3 $(15 \%)$ \\
\hline h1 $(45 \%)$ & $\begin{array}{rl}4,09 & \mathrm{C} \\
\mathrm{a} & \end{array}$ & $\begin{array}{rr}4,13 & \mathrm{C} \\
\mathrm{a} & \end{array}$ & $\begin{array}{cc}4,18 & \\
\\
\text { a } & \end{array}$ \\
\hline h2 (50\%) & $\begin{array}{rr}3,61 & \text { B } \\
\text { b } & \end{array}$ & $\begin{array}{rr}3,68 & B \\
b & \end{array}$ & $\begin{array}{ll}3,48 & \text { B } \\
& \\
\text { a } & \end{array}$ \\
\hline h3 (55\%) & $\begin{array}{rr}3,40 & \text { A } \\
b & \end{array}$ & $\begin{array}{r}\mathrm{A} \\
2,98 \\
\mathrm{a}\end{array}$ & $\begin{array}{ll}3,04 & \mathrm{~A} \\
\mathrm{a} & \end{array}$ \\
\hline
\end{tabular}

Hasil analisis variansi tekstur pada tabel 9 menunjukkan hasil pada perlakuan w1 (konsentrasi wortel 5\%) dan w2 (konsentrasi wortel 10\%) berbeda nyata dengan perlakuan w3 (konsentrasi wortel 15\%). Tabel 9 menunjukkan semakin bertambah nya wortel tekstur semakin kurang disukai. Nugget nabati semakin banyak penambahan wortel mengakibatkan tekstur yang lembek dan kurang disukai oleh panelis. Hal ini dikarenakan wortel memiliki kadar air yang cukup tinggi sebesar 88\% (Direktorat gizi, Depkes RI, 1996). Kadar air yang besar ini menyebabkan ketika diparut, wortel yang dihasilkan memiliki tekstur yang lembek dan kurang disukai.

\section{c. Aroma}

Berdasarkan hasil analisis variansi, menunjukkan bahwa faktor $\mathrm{H}$ (konsentrasi ampas kecap) berpengaruh nyata terhadap aroma nugget nabati, sedangkan faktor W (konsentrasi wortel) dan interaksi HW (konsentrasi ampas kecap dan konsentrasi wortel) tidak berpengaruh nyata terhadap aroma nugget nabati. Tabel pengaruh konsentrasi ampas kecap dapat dilihat pada tabel 10.

Tabel 10. Tabel Pengaruh Konsentrasi Ampas Kecap terhadap Aroma Nugget Nabati

\begin{tabular}{|c|c|}
\hline $\begin{array}{c}\text { Konsentrasi Ampas Kecap } \\
(\mathrm{H})\end{array}$ & Aroma \\
\hline h1 $(45 \%)$ & $4,13 \mathrm{~b}$ \\
\hline h2 $(50 \%)$ & $4,03 \mathrm{~b}$ \\
\hline h3 $(55 \%)$ & $3,62 \mathrm{a}$ \\
\hline
\end{tabular}

Keterangan : Setiap huruf yang berbeda menunjukkan perbedaan yang nyata berdasarkan Uji Lanjut Duncan pada taraf 5\%

Hasil analisis tekstur pada tabel 10 dapat diketahui bahwa perlakuan h1 (konsentrasi ampas kecap 45\%) dan h2 (konsentrasi ampas kecap 50\%) berbeda nyata dengan perlakuan dan h3 (konsentrasi ampas kecap $55 \%$ ). Semakin banyak penambahan ampas kecap maka aroma pada nugget semakin kurang disukai oleh panelis. Hal ini dikarenakan ampas kecap memiliki aroma langu yang khas. Bau dan rasa langu merupakan salah satu masalah dalam pengolahan kedelai. Rasa langu yang tidak disukai ini dihasilkan oleh adanya enzim lipoksidase pada kedelai. Hal ini terjadi karena enzim lipoksidase menghidrolisis atau menguraikan lemak kedelai menjadi senyawa - senyawa penyebab bau 
langu, yang tergolong pada kelompok heksanal dan heksanol. Senyawa-senyawa tersebut dalam kosentrasi rendah sudah dapat menyebabkan bau langu (Sutrisno K, 2009).

\section{d. Rasa}

Hasil analisis variansi, bahwa faktor $\mathrm{H}$ (konsentrasi ampas kecap), faktor W (konsentrasi wortel) dan interaksi HW (konsentrasi ampas kecap dan konsentrasi wortel) berpengaruh nyata terhadap rasa nugget nabati. Pengaruh interaksi konsentrasi ampas kecap dan konsentrasi wortel dapat dilihat pada Tabel 11.

Tabel 11. Pengaruh Interaksi Konsentrasi Ampas Kecap dan Konsentrasi Wortel terhadap Rasa Nugget Nabati

Keterangan : Setiap huruf yang berbeda menunjukkan perbedaan yang nyata berdasarkan Uji Lanjut Duncan pada taraf 5\%. Huruf kecil dibaca horizontal, huruf kapital dibaca vertikal

Hasil tabel 11 menunjukkan pada perlakuan h1 (konsentrasi ampas kecap 45\%) tidak berpengaruh nyata terhadap w1 (konsentrasi wortel 5\%), w2 (konsentrasi wortel 10\%), dan w3 (konsentrasi wortel 15\%). Pada perlakuan h2 (konsentrasi ampas kecap 50\%) berpengaruh nyata terhadap w1 (konsentrasi wortel 5\%) dan w2 (konsentrasi wortel 10\%) tapi tidak berpengaruh nyata terhadap w3 (konsentrasi wortel 15\%). Pada perlakuan h3 (konsentrasi ampas kecap 50\%) berpengaruh nyata terhadap w1 (konsentrasi wortel 5\%) tapi tidak berpengaruh nyata terhadap w2 (konsentrasi wortel 10\%) dan w3 (konsentrasi wortel 15\%). Hal ini menunjukkan penambahan wortel $5 \%, 10 \%$, dan $15 \%$ pada nugget nabati tidak berpengaruh nyata terhadap rasa nugget nabati.

Tabel 11 menunjukkan semakin bertambah konsentrasi ampas kecap maka nugget semakin kurang disukai oleh panelis. Hal ini dikarenakan adanya aftertaste pahit pada nugget. Aftertaste pahit merupakan salah satu kelemahan rasa pada ampas kecap. Disamping rasa langu, faktor penyebab "off-flavor" yang lain dalam kedelai adalah rasa pahit dan rasa kapur yang disebabkan oleh adanya senyawa-senyawa glikosida dalam biji kedelai. Diantara glikosidaglikosida tersebut, soyasaponin dan sapogenol merupakan penyebab rasa pahit yang utama dalam kedelai dan produk-produk non fermentasinya. Senyawa glikosida lain yang menyebabkan "off-flavor" pada kedelai adalah isoflavon dan gugus aglikonya. Glikosida tersebut menyebabkan timbulnya rasa kapur pada susu kedelai dan produk nonfermentasi lainnya. Senyawa isoflavon dalam kedelai terdiri dari genistin dan daidzin, sedangkan gugus aglikonnya masing-masing disebut genistein dan daidzein (Sutrisno, 2009).

Berdasarkan hasil percobaan penelitian terhadap pembuatan nugget nabati yang telah dilakukan dapat ditarik kesimpulan sebagai berikut:

1. Pada penelitian pendahuluan berdasarkan hasil uji kadar garam, didapat kadar garam ampas kecap sebelum perendaman sebesar $11,68 \%$ dan mengalami penurunan setelah direndam selama 24 jam menjadi 4,76\%. Pada kadar protein dan kadar serat, didapat kadar protein ampas kecap sebesar 16,98\% dan kadar serat 13,3\%.

2. Konsentrasi ampas kecap $(\mathrm{H})$ berpengaruh terhadap kadar air, protein, serat kasar, lemak, kenampakan, aroma, rasa, dan tekstur.

3. Konsentrasi wortel (W) berpengaruh terhadap serat kasar, kadar air, tekstur, rasa dan kenampakan tetapi tidak berpengaruh terhadap protein, lemak, dan aroma.

4. Interaksi konsentrasi ampas kecap (H) dan konsentrasi wortel (W) berpengaruh terhadap kenampakan dan rasa tetapi tidak berpengaruh terhadap kadar air, protein, serat kasar, lemak, aroma, dan tekstur.

\section{Daftar Pustaka}

1. Almatsier, S. (2000) Prinsip Dasar Ilmu Gizi. Jakarta: PT. Gramedia Pustaka Utama.

2. AOAC. 2010. Official Methods of Analysis of the Association of the Official Analytical Chemist. Washington D. C., USA.

3. Bjarnadottir, A. 2015. Carrots 101: Nutrition Facts and Health Benefits. WebMD

4. Direktorat Gizi Departemen Kesehatan RI. 1996. Daftar Komposisi Zat Gizi Pangan Indonesia.

5. Koswara, S. 2006. Konsumsi Lemak yang Ideal Bagi Kesehatan. Ebook pangan. http://ebookpangan.com. Diakses pada tanggal 01 November 2019.

6. Saleh. 2002. Kumpulan Hasil-Hasil Penelitian Pasca Panen Perikanan. Pusat Riset Pengolahan Produk dan Sosial Ekonomi Kelautan dan Perikanan. DKP. Jakarta.

7. Santoso, Umar. 1987. Limbah Bahan Ransum Unggas. Jakarta: PT. Bayangkara Aksara.

8. Sundari, D., Almasyuhri., dan Lamid, A. 2015. Pengaruh Proses Pemasakan terhadap Komposisi Zat Gizi Bahan Pangan Sumber Protein. Media litbangkes Volume 25 Nomor 4. Program Studi Teknologi Pangan Fakultas Pertanian Universitas Tanjungpura.

9. Tensiska, 2008. Serat Makanan. Jurusan Teknologi Industri Pangan. Fakultas Teknologi Industri Pertanian. Universitas Padjadjaran, Bandung

10. United States Department of Agriculture. 2007. USDA National Nutrient Database for Standard Reference. http://www.nal.usda.gov/fnic/foodcomp/cgibin/list_nut_edit.pl. Diakses: 16 Mei 2019

11. Winarno, F. G. 1992. Kimia Pangan dan Gizi. Jakarta: Gramedia Pustaka Utama

12. Winarno, F. G., S, Fardiaz., dan D, Fardiaz. 1980. Penghantar Teknologi Pangan. Jakarta: Gramedia 